\title{
Diyabetik Maküla Ödemi Tedavisinde Serum HbA1c Düzeyinin İntravitreal Anti-VEGF Tedavisine Etkisi
}

\author{
Sait ALİM ${ }^{1} \bowtie$, Ayşe Kevser DEMİR² \\ ${ }^{1}$ Gaziosmanpaşa Üniversitesi Tıp Fakültesi, Göz Hastalıkları Anabilim Dalı, Tokat \\ ${ }^{2}$ Gaziosmanpaşa Üniversitesi Tıp Fakültesi, İç Hastalıkları Anabilim Dalı, Tokat \\ Bu makaleye yapılacak atıf: Alim S, Demir AK. Diyabetik Maküla Ödemi Tedavisinde Serum HbAlc Düzeyinin İntravitreal Anti-VEGF Tedavisine Etkisi. \\ Türk Diyab Obez 2019;2: 79-83.
}

\begin{abstract}
ÖZET
Amaç: Diyabetik maküla ödemi (DMÖ) tedavisi için intravitreal vasküler endotelyal büyüme faktör inhibitörü (anti-VEGF) tedavisi alan hastalarda enjeksiyon esnasında serum glikolize hemoglobin Alc (HbAlc) düzeyinin tedavi başarısına etkisini incelemektir.

Gereç ve Yöntemler: Çalışmaya ilk kez DMÖ nedenli anti-VEGF tedavisi alan ve HbA1c düzeyi son 2 hafta içinde çalışılmış hastaların sadece tek gözleri alındı. Daha önce makülaya lazer yapılan, son 3 ay içinde göz cerrahisi geçiren, vitreomaküler ara yüzey patolojisi olan ve vitreus ya da premaküler hemorajisi olan olgular dahil edilmedi. Hastaların etkilenen gözleri, Snellen eşeli ile en iyi düzeltilmiş görme keskinlikleri (EIDGK), dilate fundus muayene bulguları, fundus floresein anjiyografileri, tedavi öncesi ve tedaviden 1 ay sonraki optik koherens tomografi (OKT) ile elde edilen santral maküla kalınlığ (SMK) ve uygulanan anti-VEGF türü kaydedildi. Hastalar HbA1c düzeyi $<9,0 \mathrm{mg} / \mathrm{dl}$ (grup 1, 23 göz) ve $\geq 9,0 \mathrm{mg} / \mathrm{dl}$ (grup 2, 34 göz) olarak iki gruba ayrllarak analiz edildi.

Bulgular: Çalışmaya 31’i $(\% 54,4)$ kadın olmak üzere 57 birey dahil edildi. Hastaların yaş ortalaması $61,1 \pm 11,9$ idi. İntravitreal antiVEGF olarak 31 göze $(\% 54,4)$ ranibizumab, $26(\% 45,6)$ göze ise aflibercept uyguland1. Hastaların ortalama HbA1c düzeyi 9,35 $\pm 1,8[6,5$ $13,6] \mathrm{mg} / \mathrm{dl}$ iken kadın ve erkek hastalar arasında fark yoktu $(\mathrm{p}=0,570)$. İki grup yaş, cinsiyet, göz ve uygulanan anti-VEGF açısından istatistiksel olarak farklı değildi ( $>00,05)$. Tedavi sonrası SMK azalması grup 1'de $164 \mu$ iken grup 2'de $138 \mu$ idi ( $\mathrm{p}=0,714)$. Tedavi ile EIDGK artışı grup 1'de 0,23 ve grup 2'de 0,12 idi ( $\mathrm{p}=0,001)$.
\end{abstract}

Sonuç: Çalışmamıza göre serum HbA1c düzeyi intravitreal anti-VEGF tedavisinin ilk bir ayında anatomik başarı üzerine bariz bir etki oluşturmazken HbA1c düzeyinin düşük olması fonksiyonel başarıda artış ile ilişkili bulunmuştur.

Anahtar Sözcïkler: Diyabetik maküla ödemi, HbA1c, Anti-VEGF, Ranibizumab, Aflibercept

\section{The Effect of Serum HbAlc Level on Intravitreal Anti-VEGF Treatment for Diabetic Macular Edema}

\begin{abstract}
Aim: To investigate the effect of serum glycosylated hemoglobin A1C (HbAlc) on treatment success in patients receiving intravitreal vascular endothelial growth factor inhibitor (anti-VEGF) treatment for diabetic macular edema (DME).

Material and Methods: The study included only one eye of patients who received anti-VEGF therapy for the first time and who had checked blood HbA1c levels in the last two weeks. Patients with vitreomacular interface pathology and vitreous or premacular hemorrhage were excluded from the study. The affected eyes of the patients, the best corrected visual acuity (BCVA) with Snellen chart, dilated fundus examination findings, fundus fluorescein angiography, central macular thickness (SMK) measurements (pre-treatment and 1 month after treatment) obtained by optical coherence tomography (OCT), and used type of anti-VEGF agents were recorded. Patients were divided into two groups as HbAlc level $<9.0 \mathrm{mg} / \mathrm{dl}$ (group 1, 23 eyes) and $\geq 9.0 \mathrm{mg} / \mathrm{dl}$ (group 2, 34 eyes).
\end{abstract}

ORCID: Sait Alim / 0000-0003-1237-4264, Ayşe Kevser Demir / 0000-0002-9993-5265 
Results: There were 54 patients, of them $54.4 \%$ were female included in the study. The mean age of the patients was $61.1 \pm 11.9$ years. Twenty-one eyes (54.4\%) were received ranibizumab as intravitreal anti-VEGF injection and remained 26 (45.6\%) eyes were received aflibercept. The mean HbA1c level of the patients was $9.35 \pm 1.8$ [6.5-13.6] $\mathrm{mg} / \mathrm{dl}$, while there was no difference between the male and female patients $(\mathrm{p}=0,570)$. The two groups were not statistically different in terms of age, gender, eye laterality and anti-VEGF agents used ( $p>0.05)$. While the decrease in SMC after the treatment was $164 \mu$ in group 1 , it was $138 \mu$ in group $2(p=0.714)$. The increase in BCVA was 0.23 in group 1 and 0.12 in group $2(\mathrm{p}=0.001)$.

Conclusion: Our study revealed that serum HbA1c level did not have a significant effect on anatomical success at the first month of intravitreal anti-VEGF treatment, whereas low HbA1c level was associated with increased functional success.

Key Words: Diabetic macular edema, HbA1c, Anti-VEGF, Ranibizumab, Aflibercept.

\section{GIRIŞ}

Diyabet hastalarında görme azlığının en önemli nedeni diyabetik maküler ödemdir (DMÖ) (1). Retina içi sıvı artışı neticesi maküla kalınlığında artış ile kendini belli eden bu hastalıkta retinal vasküler permeabilite artışının bu duruma neden olduğu düşünülmektedir. Diyabetik makula ödemi oluşumundaki birçok risk faktöründen en önemlisi diyabetin süresi ve kan şeker regülasyonudur. Hipertansiyon, dislipidemi, gebelik ve nefropati varlığ ise diğer önemli risk faktörleridir (2).

Kan şekeri regülasyonunun bir göstergesi olarak kullanılan glikolize hemoglobin A1c (HbAlc) değeri diyabetik retinopati ve DMÖ ile yakından ilişkilidir $(3,4)$. İnsülin bağımlı diyabet hastalarının 4 yıl izlendiği bir çalışmada $\mathrm{HbA1C}$ düzeyinin $12 \mathrm{mg} / \mathrm{dl}$ ve üzeri olanlarda $3,2 \mathrm{~kat}$ daha fazla diyabetik retinopati görüldügü tespit edilmiş (5). United Kingdom Prospective Diabetes Study (UKPDS) verilerine göre ortanca $\mathrm{HbA1c}$ düzeyinin $\% 11$ azaltılması diyabete bağlı mikrovasküler komplikasyonları \%25 azaltabilmektedir (6).

Görme keskinliğinde azalmanın ve makülada oluşan ödemin tedavisinde güncel tedavi seçeneklerinden en önemlisi vitreus boşluğuna vasküler endotelyal büyüme faktörü (VEGF) blokörü (anti-VEGF) verilmesidir. Standart olarak ayda bir olmak üzere 3 yükleme dozu sonrası görme keskinliğinde artışın devam ettiği ve maküla ödeminin tam geçmediği olgularda tekrar göz içi anti-VEGF enjeksiyonu yapılması önerilmektedir (7). Son zamanlarda yapilan çalışmalar doğrultusunda bu tedavinin ilk yılında yaklaşık 7-9 enjeksiyon gerekli olunurken ikinci yılında bu sayı 3-4 kadar olmaktadır (8). Göz içi enjeksiyonun endoftalmi gibi ağır komplikasyonlar barındırması, enjeksiyonun hastalarda oluşturduğu stres ve tedavi için sık hastaneye gelme gereksinimi gibi nedenlerden dolayı etkin tedavi yapmanın yanında enjeksiyon sayısını azaltma girişimleri vardır. $\mathrm{Bu}$ amaçla farklı farmakolojik ajanlar üzerinde çalışmalar devam ederken bireye sistematik yaklaşımla kan şekeri ve hipertansiyon başta olmak üzere diğer risk faktörlerinin regülasyonu önemli rol oynamaktadır. $\mathrm{Bu}$ nedenle biz çalışmamızda göz içi anti-VEGF tedavisi anında kan şeker regülasyonunun göstergesi olan $\mathrm{HbAlc}$ düzeyinin tedavi başarısı üzerine etkisini araştırdık.

\section{GEREÇ ve YÖNTEMLER}

Çalışmada 01.01.2018 ile 01.01.2019 tarihleri arasında Tokat Gaziosmanpaşa Üniversitesi Göz Hastalıkları Polikliniğine başvuran hastalardan ilk kez DMÖ nedenli anti-VEGF tedavisi alan hastalar geriye dönük olarak araştırıldı. Bu çalışma Tokat Gaziosmanpaşa Üniversitesi Tip Fakültesi Etik kurulundan onayı alınarak yapıldı (18.06.2019 onay no:19-KAEK-152). Daha önce makülaya lazer yapılan, son 3 ay içinde göz cerrahisi geçiren, vitreomaküler ara yüzey patolojisi olan ve vitreus ya da premaküler hemorajisi olan olgular dahil edilmedi. Hastaların, dilate fundus muayene bulguları, fundus floresein anjiyografileri, tedavi öncesi ve tedaviden bir ay sonraki ile elde edilen santral maküla kalınlığ $($ SMK) ve uygulanan anti-VEGF türü kaydedildi.

Tüm hastaların göz içi basınç ölçümleri ve Snellen eşeli ile en iyi düzeltilmiş görme keskinlikleri (EİDGK) ölçüldü. Pupil dilatasyonu için bir kez tropamid veya sikloplejin damla sonrası en az 30 dakika beklendikten sonra biyomikroskop ile fundus muayenesi yapıldı. Mikroanevrizma, mikrohemoraji, sert eksüda, yumuşak eksüda, intraretinal mikrovasküler anomali ve maküla kalınlığında artış gibi diyabetik retinopati varlığında fundus floresein anjiografisi (FFA) ve optik koherens tomografi (OKT) tetkikleri yapıldı. FFA tetkikinde maküla bölgesinde sızıntı olan ve OCT bulgularında maküla kalınlığında artış görülen hastalara DMÖ tanısı konuldu. Bu hastalara tedavi olarak intraoküler aflibercept ya da ranibizumab enjeksiyonu yapıldı. Tedavi steril şartlar altında üst temporal bölgeden yaklaşılarak 30 gauge enjektör yardımıyla etken maddeden bağımsız olarak $0,05 \mathrm{ml}$ miktarında yapıldı. Fakik hastalarda limbusun 3,5 mm uzağından, psödofak hastalarda ise limbusun 3,0 $\mathrm{mm}$ uzağından göz içine giriş sağlandı. İşlem sonrası 3 gün topikal antibiyotik tedavisi verildi. Hastaların muayene öncesi ve 1. ay kontrol muayene bulguları kaydedildi. Enjeksiyondan iki hafta önce veya iki hafta sonrası arasında HbA1c değeri hastanemizde kayıtlı hastalar bu çalışmaya dahil 
edildi. HbA1c düzeyi $<9,0 \mathrm{mg} / \mathrm{dl}$ (grup 1, 23 göz) ve $\geq 9,0$ $\mathrm{mg} / \mathrm{dl}$ (grup 2, 34 göz) olmak üzere hastalar iki gruba ayrıldı.

Veriler SPSS 18,0 istatistik programına aktarılarak analiz edildi. Veriler aritmetik ortalama \pm SD olarak verildi. Verilerin normal dağılıma uygun olup olmadığını ortaya koymak amacıyla Shapiro-Wilk testi kullanıldı. Kategorik veriler Ki-kare, sürekli değişkenler ise İki Ortalama Arasındaki Farkın Önemlilik testi ile karşılaştırıldı. Tekrarlı ölçümlerde üç yönlü varyans analizi ile tedavi uygulanan intravitreal ajan, tedavi öncesi ve sonrası SMK ile hastaların kategorize edilmiş $\mathrm{HbA} 1 \mathrm{c}$ değerleri incelendi. İstatistiksel anlamlılık için $\mathrm{p}<0,05$ kabul edildi.

\section{BULGULAR}

Çalışmaya 31'i $(\% 54,4)$ kadın 57 hasta dahil edildi. Hastaların yaş ortalaması $61,1 \pm 11,9$ idi. Hastaların $30^{\prime} \mathrm{u}$ $(\% 52,6)$ sağ gözden tedavi alırken intravitreal olarak 31 göze $(\% 54,4)$ ranibizumab $26(\% 45,6)$ göze ise aflibercept tedavisi uygulandı. Hastaların ortalama HbA1C düzeyi 9,35 $\pm 1,8$ $[6,5-13,6] \mathrm{mg} / \mathrm{dl}$ iken kadın ve erkek hastalar arasında fark yoktu $(\mathrm{p}=0,570)$. İki grup yaş, cinsiyet, göz ve uygulanan anti-VEGF açısından istatistiksel farklı değildi ( $p>0,05)$. Hasta gruplarının genel karakteristik özellikleri Tablo 1'de detaylı olarak sunulmuştur.
Her iki grupta tedavi sonrası maküla kalınlığı istatistiksel olarak anlamlı düzeyde azalma gösterdi $(\mathrm{p}<0,001)$. SMK'da azalma grup 1'de $164 \mu$ iken grup 2'de $138 \mu$ idi $(p=0,714)$. Uygulanan intravitreal anti-VEGF'ler arası karşılaştırma yapıldığında SMK azalması yönünden anlamlı farklılık yoktu $(\mathrm{p}=0,509)$. Santral maküla kalınlığının uygulanan tedavi ile değişimi Tablo 2'de detaylica sunulmuştur. AntiVEGF tedavi ile EIDGK artışı grup 1'de 0,23 iken grup 2'de 0,12 idi $(p=0,001)$.

\section{TARTIŞMA}

Çalışmamızda DMÖ nedenli görme azlığının tedavisinde intavitreal anti-VEGF tedavi ile görme keskinliğinde anlamlı düzeyde artış oldu. Görme keskinliğindeki bu artış HbA1c düzeyi düşük olan grupta anlaml düzeyde daha fazlaydı. Görme keskinliğinde artışın yanında maküla ödeminde düzelme oldu. Anti-VEGF tedavisi ile 1. ayda maküla kalınlığında yaklaşık $150 \mu$ azalma görüldü. Maküla ödeminde görülen bu azalma uygulanan anti-VEGF ajanlar olan aflibercept ve ranibizumab tedavi seçenekleri arasında fark göstermedi. Maküla kalınlığındaki bu azalma HbAlc'ye göre oluşturulan gruplar arasında anlamlı değişiklik göstermedi.

Tablo 1: Hasta gruplarının tedavi öncesi genel karakteristik özelliklerinin sunumu.

\begin{tabular}{lccc}
\hline & Grup 1 (n=23) & Grup 2 (n=34) & p \\
\hline Yaş (yıl) & $60,8 \pm 14,1$ & $61,2 \pm 10,3$ & 0,914 \\
\hline Cinsiyet (kadın/erkek) & $13 / 10$ & $18 / 16$ & 0,795 \\
\hline Etkilenen göz (sağ/sol) & $12 / 11$ & $18 / 16$ & 0,956 \\
\hline Görme keskinliği & $0,35 \pm 0,25$ & $0,28 \pm 0,24$ & 0,274 \\
\hline Maküla kalınlı̆̆ $(\mu)$ & $477 \pm 150$ & $497 \pm 119$ & 0,592 \\
\hline Anti-VEGF türü (aflibercept/ranibizumab) & $14 / 9$ & $17 / 17$ & 0,588 \\
\hline HbAlc mg/dl & 7,7 & 10,4 & $\mathrm{n} / \mathrm{a}$ \\
\hline
\end{tabular}

Tablo 2: Ölçümlerin tedavi ve HbA1c grubuna göre dağılımı

\begin{tabular}{llccc}
\hline \multirow{2}{*}{ Tedavi } & \multirow{2}{*}{ Zaman } & \multicolumn{2}{c}{ HbA1c grubu } & \multirow{2}{*}{ Toplam } \\
\cline { 3 - 5 } & & \multicolumn{1}{c}{$\mathbf{1}$} & $\mathbf{2}$ & \\
\hline \multirow{2}{*}{ Ranibizumab } & preop_CMT & $503,07 \pm 184,79(\mathrm{a}, \mathrm{x}, \mathrm{m})$ & $476,47 \pm 86,23(\mathrm{a}, \mathrm{x}, \mathrm{m})$ & $488,48 \pm 137,64(\mathrm{a}, \mathrm{x})$ \\
\cline { 2 - 5 } & postop_CMT & $319,43 \pm 62,86(\mathrm{a}, \mathrm{y}, \mathrm{m})$ & $340,82 \pm 79,12(\mathrm{a}, \mathrm{y}, \mathrm{m})$ & $331,16 \pm 71,89(\mathrm{a}, \mathrm{y})$ \\
\hline \multirow{2}{*}{ Aflibercept } & preop_CMT & $436,78 \pm 58,99(\mathrm{a}, \mathrm{x}, \mathrm{m})$ & $518,24 \pm 145,85(\mathrm{a}, \mathrm{x}, \mathrm{m})$ & $490,04 \pm 127,63(\mathrm{a}, \mathrm{x})$ \\
\hline \multirow{2}{*}{ Toplam } & postop_CMT & $302,78 \pm 59,41(\mathrm{a}, \mathrm{y}, \mathrm{m})$ & $378,24 \pm 112,67(\mathrm{a}, \mathrm{y}, \mathrm{n})$ & $352,12 \pm 102,93(\mathrm{a}, \mathrm{y})$ \\
\hline & preop_CMT & $477,13 \pm 150,13(\mathrm{x}, \mathrm{m})$ & $497,35 \pm 119,87(\mathrm{x}, \mathrm{m})$ & $489,19 \pm 131,99(\mathrm{x})$ \\
\hline
\end{tabular}

Tekrarlı ölçümlerde üç yönlü varyans analizi kullanıldı.

(ab): Tedavi için gruplar arası karşılaştırma, (xy): Ölçümler arası karşılaştırma, (mn): HbA1c grupları arası karşılaştırma. 
Diyabetik retinopati çalışma çağındaki yetişkin popülasyonda görme azlığının en önemli nedenidir. Bu görme azlığı diyabete bağlı katarakt, vitreus veya retina hemorajieri, traksiyone retina dekolmanı ve maküla ödemi nedenli olabilmektedir. Hastalığın erken dönemlerinde oluşan komplikasyonların tedavisinde anatomik ve fonksiyonel başarı daha iyi olurken gecikmiş olgularda tedaviden beklenen sonuçlar sinırlı kalmaktadır (9). Viteus ile Retina pigment epiteli arasinda yer alan retina görme fonksiyonunda yer alan fotoreseptör, bipolar hücre ve gangliyon hücrelerini ihtiva eden nöral bir dokudur. Işığın fotoreseptör hücrelerine ulaşabilmesi için şeffaflığını ve anatomik bağlantılarını koruması gereklidir. Diyabet hastalarında kan şeker regülasyonundaki bozukluk hücresel düzeyde etkilerini göstermeye başlar ve daha sonra hem mikrovasküler hem de makrovasküler hadiselere yol açmaktadır. Endotel disfonksiyonu, kapiller damar duvar değişkenliği, pıhtılaşmaya artmı̧ eğilim gibi nedenlerle hücre içi ve hücre dışı sıvı artışı olmakta ve bu durum retinanın şeffaflığını etkileyebildiği gibi hücrelerde strese neden olur (10). Diyabet hastalarında mikrovasküler hasarın yanında nöroglia hücrelerinde meydana gelen değişiklikler de görme azalığına neden olan bir durumdur (11).

Diyabet hastalarında görme azlığı oluşturan sebeplerin başında DMÖ gelmektedir. Vasküler geçirgenlik artışı nedenli retina kapillerlerinden sızan sıvı hücreler arası boşlukta birikmektedir. Oksidatif stres, protein kinaz C aktivasyonu ve ileri glikasyon son ürünlerinin hücresel ve reseptör düzeyindeki etkileri kapillerlerdeki sızıntı oluşumunda ön planda rol oynar (12-14). Yapılan klinik çalışmalar DMÖ gelişiminde rol alan en önemli faktörün VEGF olduğunu, VEGF blokajının vasküler sızıntıyı önleyerek maküla ödemini azaltabildiğini göstermektedir $(15,16)$. Çok merkezli yapılan protokol T çalışmasında DMÖ tedavisinde intravitreal olarak aflibercept, ranibizumab ve bevacizumab ani-VEGF tedavileri karşılaştırılmış olup ilk yıl başlangıçta görmesi daha kötü olan grupta aflibercept daha etkin bulunurken, iki yıl süren tedavi sonunda aflibercept ve ranibizumab ile benzer ve bevacizumabtan daha etkin sonuç alınmıştır (8).

Kan şekeri regülasyonunun değerlendirilmesi ve diyabet tanısinda kullanılan $\mathrm{HbAlc}$, hemoglobin $\beta$-zincirinde glikoz ve valin arasında enzimatik olmayan bir reaksiyonla gelişen bir hemoglobin türevidir. HbAlc miktarı, hipergliseminin süresi ve şiddeti ile ilişkilidir ve bu nedenle hastaların son 3 aydaki kan şekeri durumunun geriye dönük değerlendirilmesine olanak tanır. Schmid ve ark. (17) çalışmalarında HbAlc düzeyinin DMÖ tedavisinde daha önceleri uygulanan grid lazer tedavisi sonuçları üzerine etkisini incelemiş ve bir fark bulmamıştır. Shalchi ve ark.
(18) çalışmalarında başlangıç HbAlc düzeyi ile intravitreal ranibizumab uygulamasının 1 yıllık sonuçlarını incelemiş ve başlangıç HbAlc düzeyinin tedavi başarısına anlamlı bir etkisi bulunmamıştır. Başlangıç HbA1C değerinin tedavinin 1 yıl süresince nasıl değiştiği ise bu çalışmalarında bildirilmemiş olup sonuca bir etkisi olabileceği göz önünde bulundurulmalıdır.

Çalışmamızda başlangıç HbA1c düzeyi ile 1 aylık tedavi sonuçları incelenmiştir. Protokol T çalışmasında önerildiği gibi ilk 3 ay aylık yükleme dozu uygulanan hastalarımızın 1. ay sonuçları karşılaştırılmış olup bu süre içinde HbAlc düzeyinin anlamlı değişim beklenmemektedir. $\mathrm{Bu}$ çalışmada her iki anti-VEGF ajan ile benzer şekilde SMK azalması elde edilirken görme keskinliğinde artış elde edildi. SMK azalması HbAlc düzeyinden etkilenmezken görme keskinliği artışı HbA1c düzeyi düşük olan grupta daha fazla oldu. $\mathrm{Bu}$ durum kan şekeri regülasyonunun intravitreal anti-VEGF tedavisinin ilk bir ayında anatomik başarı üzerine bariz bir etki yapmaz iken fonksiyonel başarıyı artırabileceği kanaatini oluşturmuştur.

\section{KAYNAKLAR}

1. Kitano S, Sakamoto T, Goto R, Fukushima A, Vataire AL, Hikichi Y. The impact of anti-vascular endothelial growth factor agents on visual impairment/blindness prevention in patients with diabetic macular edema and on associated patient and caregiver burden in Japan. J Med Econ. 2019;22:254-265.

2. Acan D, Calan M, Er D, Arkan T, Kocak N, Bayraktar F, Kaynak S. The prevalence and systemic risk factors of diabetic macular edema: A cross-sectional study from Turkey. BMC Ophthalmol. 2018;18:91.

3. Hemmingsen B, Lund SS, Gluud C, Vaag A, Almdal T, Hemmingsen C, Wetterslev J. Intensive glycaemic control for patients with type 2 diabetes: Systematic review with metaanalysis and trial sequential analysis of randomised clinical trials. BMJ. 2011;343:d6898.

4. Wang PH, Lau J, Chalmers TC. Meta-analysis of effects of intensive blood-glucose control on late complications of type I diabetes. Lancet. 1993;341:1306-1309.

5. Klein R, Palta M, Allen C, Shen G, Han DP, D'Alessio DJ. Incidence of retinopathy and associated risk factors from time of diagnosis of insulin-dependent diabetes. Arch Ophthalmol. 1997;115:351-356.

6. Intensive blood-glucose control with sulphonylureas or insulin compared with conventional treatment and risk of complications in patients with type 2 diabetes (UKPDS 33). UK Prospective Diabetes Study (UKPDS) Group. Lancet 1998;352:837-853.

7. Calugaru D, Calugaru M. Anti-VEGF treatment for diabetic macular edema in a Real-World Clinical setting. Am J Ophthalmol. 2018;196:208-209. 
8. Wells JA, Glassman AR, Ayala AR, Jampol LM, Bressler NM, Bressler SB, et al. Aflibercept, Bevacizumab, or Ranibizumab for Diabetic Macular Edema: Two-Year Results from a Comparative Effectiveness Randomized Clinical Trial. Ophthalmology. 2016;123:1351-1359.

9. Antonetti DA, Barber AJ, Bronson SK, Freeman WM, Gardner TW, Jefferson LS, et al. Diabetic retinopathy: Seeing beyond glucose-induced microvascular disease. Diabetes. 2006;55:2401-2411.

10. Wangsa-Wirawan ND, Linsenmeier RA. Retinal oxygen: Fundamental and clinical aspects. Arch Ophthalmol. 2003;121:547-557.

11. Dodo Y, Murakami T, Suzuma K, Yoshitake S, Yoshitake T, Ishihara K, Fujimoto M, Miwa Y, Tsujikawa A. Diabetic neuroglial changes in the superficial and deep nonperfused areas on optical coherence tomography angiography. Invest Ophthalmol Vis Sci. 2017;58:5870-5879.

12. Hudson BI, Schmidt AM. RAGE: A novel target for drug intervention in diabetic vascular disease. Pharm Res. 2004;21:1079-1086.

13. Aiello LP. The potential role of PKC beta in diabetic retinopathy and macular edema. Surv Ophthalmol. 2002;47 Suppl 2:S263-269.
14. Caldwell RB, Bartoli M, Behzadian MA, El-Remessy AE, AlShabrawey M, Platt DH, Liou GI, Caldwell RW. Vascular endothelial growth factor and diabetic retinopathy: Role of oxidative stress. Curr Drug Targets. 2005;6:511-524.

15. Funatsu H, Yamashita H, Noma H, Mimura T, Yamashita T, Hori S. Increased levels of vascular endothelial growth factor and interleukin- 6 in the aqueous humor of diabetics with macular edema. Am J Ophthalmol. 2002;133:70-77.

16. Murakami T, Frey T, Lin C, Antonetti DA. Protein kinase cbeta phosphorylates occludin regulating tight junction trafficking in vascular endothelial growth factor-induced permeability in vivo. Diabetes. 2012;61:1573-1583.

17. Schmid KE, Neumaier-Ammerer B, Stolba U, Binder S. Effect of grid laser photocoagulation in diffuse diabetic macular edema in correlation to glycosylated haemoglobin (HbA1c). Graefes Arch Clin Exp Ophthalmol. 2006;244:1446-1452.

18. Shalchi Z, Okada M, Bruynseels A, Palethorpe D, Yusuf A, Hussain R, et al. Effect of glycosylated hemoglobin on response to ranibizumab therapy in diabetic macular edema: Real-world outcomes in 312 patients. Can J Ophthalmol. 2018;53:415-419. 
